\title{
Republication of: Elevating the quality of disability and rehabilitation research: Mandatory use of the reporting guidelines
}

\author{
Leighton Chan ${ }^{1 *}$, Allen W. Heinemann ${ }^{2}$ and Jason Roberts ${ }^{3}$
}

\begin{abstract}
Journal of NeuroEngineering and Rehabilitation advocates the complete and transparent reporting of research and methods, and is pleased to be part of an initiative to mandate the use of reporting guidelines. This Editorial is a republication of a previously published Editorial in Archives of Physical Medicine and Rehabilitation (http://dx.doi.org/ 10.1016/j.apmr.2013.12.010), and is republished here under the terms of the Creative Commons AttributionNonCommercial-NoDerivs 3.0 License (http://creativecommons.org/licenses/by-nc-nd/3.0/). For citation purposes, please use the original publication details: Chan L, Heinemann AW, Roberts J. Elevating the Quality of Disability and Rehabilitation Research: Mandatory use of the Reporting Guidelines. Arch Phys Med Rehabil. 2014;95:415-7.
\end{abstract}

\section{Editorial}

With the remarkable growth of disability- and rehabilitationrelated research in the last decade, it is imperative that we support the highest quality research possible. With cuts in research funding, rehabilitation research is now under a microscope like never before, and it is critical that we put our best foot forward.

To ensure the quality of the disability and rehabilitation research that is published, the 28 rehabilitation journals simultaneously publishing this editorial (see acknowledgments) have agreed to take a more aggressive stance on the use of reporting guidelines. ${ }^{1}$ Research reports must contain sufficient information to allow readers to understand how a study was designed and conducted, including variable definitions, instruments and other measures, and analytical techniques [1]. For review articles, systematic or narrative, readers should be informed of the rationale and details behind the literature search strategy. Too often articles fail to include their standard for inclusion and their criteria for evaluating quality of the studies [2]. As noted by Doug Altman, co-originator of the Consolidated Standards of Reporting Trials (CONSORT) statement and head of the Centre for Statistics in Medicine at Oxford University: "Good reporting is not an optional extra: it is

\footnotetext{
* Correspondence: Ichan@acrm.org

${ }^{1}$ American Congress of Rehabilitation Medicine, 11654 Plaza America Drive, Suite 535, Reston, VA 20190, USA

Full list of author information is available at the end of the article
}

an essential component of good research...we all share this obligation and responsibility" [3].

\section{What are reporting guidelines?}

Reporting guidelines are documents that assist authors in reporting research methods and findings. They are typically presented as checklists or flow diagrams that lay out the core reporting criteria required to give a clear account of a study's methods and results. The intent is not just that authors complete a specific reporting checklist but that they ensure that their articles contain key elements. Reporting guidelines should not be seen as an administrative burden; rather, they are a template by which an author can construct their articles more completely.

Reporting guidelines have been developed for almost every study design. More information on the design, use, and array of reporting guidelines can be found on the website for the Enhancing the Quality and Transparency of Health Research (EQUATOR) network [4], an important organization that promotes improvements in the accuracy and comprehensiveness of reporting. Examples include the following:

(1)CONSORT for randomized controlled trials (www.consort-statement.org); 
(2) Strengthening the Reporting of Observational studies in Epidemiology (STROBE) for observational studies (http://strobe-statement.org/);

(3) Preferred Reporting Items for Systematic Reviews and Meta-Analyses (PRISMA) for systematic reviews and meta-analyses (www.prisma-statement.org/);

(4) Standards for the Reporting of Diagnostic accuracy studies (STARD) for studies of diagnostic accuracy (www.stard-statement.org/); and

(5)Case Reports (CARE) for case reports (www.carestatement.org/).

There is accumulating evidence that the use of reporting guidelines improves the quality of research. Turner et al. [5] established that the use of the CONSORT statement improved the completeness of reporting in randomized controlled trials. Diagnostic accuracy studies appeared to show improvement in reporting standards when the STARD guidelines were applied [6]. Early evidence also suggests that inclusion of reporting standards during peer review raises manuscript quality [7]. The International Committee of Medical Journal Editors now encourages all journals to monitor reporting standards and collect associated reporting guideline checklists in the process [8]. Furthermore, the National Library of Medicine also now actively promotes the use of reporting guidelines [9].

\section{How will reporting guidelines be integrated into manuscript flow?}

By January 1, 2015, all of the journals publishing this editorial will have worked through implementation and the mandatory use of guidelines and checklists will be firmly in place. Because each journal has its unique system for managing submissions, there may be several ways that these reporting requirements will be integrated into the manuscript flow. Some journals will make adherence to reporting criteria and associated checklists mandatory for all submissions. Other journals may require them only when the article is closer to acceptance for publication. In any case, the onus will be on the author not only to ensure the inclusion of the appropriate reporting criteria but also to document evidence of inclusion through the use of the reporting guideline checklists. Authors should consult the Instructions for Authors of participating journals for more information.

We hope that simultaneous implementation of this new reporting requirement will send a strong message to all disability and rehabilitation researchers of the need to adhere to the highest standards when performing and disseminating research. Although we expect that there will be growing pains with this process, we hope that within a short period, researchers will begin to use these guidelines during the design phases of their research, thereby improving their methods. The potential benefits to authors are obvious: articles are improved through superior reporting of a study's design and methods, and the usefulness of the article to readers is enhanced. Reporting guidelines also allow for greater transparency in reporting how studies were conducted and can help, hopefully, during the peer review process to expose misleading or selective reporting. Reporting guidelines are an important tool to assist authors in the structural development of a manuscript, eventually allowing an article to realize its full potential.

Leighton Chan, MD, MPH

Allen W. Heinemann, PhD

Co-Editors-in-Chief

Archives of Physical Medicine and Rehabilitation

Jason Roberts, $\mathrm{PhD}$

Origin Editorial

\section{Endnotes}

${ }^{1}$ Physical Therapy, the Journal of Orthopaedic \& Sports Physical Therapy, the Journal of Physiotherapy, and the European Journal of Physical and Rehabilitation Medicine have already successfully required reporting guidelines, one for as many as 10 years.

\section{Acknowledgments}

As this issue went to press, the following Editors agreed to participate in the initiative to mandate reporting guidelines and publish this Position

Statement in their respective journals. As a collective group, we encourage others to adopt these guidelines and welcome them to share this editorial with their readerships.

- Sharon A. Gutman, PhD, OTR

Editor-in-Chief

American Journal of Occupational Therapy

- Walter R. Frontera, MD, PhD

Editor-in-Chief

American Journal of Physical Medicine and Rehabilitation

- Leighton Chan, MD, MPH, and Allen W. Heinemann, PhD

Co-Editors-in-Chief

Archives of Physical Medicine and Rehabilitation

- Helene J. Polatajko, PhD, OT(C)

Editor-in-Chief

Canadian Journal of Occupational Therapy

- Derick T. Wade, MD

Editor-in-Chief

Clinical Rehabilitation

- Suzanne McDermott, PhD, and Margaret A. Turk, MD

Co-Editors-in-Chief

Disability and Health Journal

- Stefano Negrini, MD

Editor-in-Chief

European Journal of Physical and Rehabilitation Medicine

- Steven Vogel, DO(Hon)

Editor-in-Chief

The International Journal of Osteopathic Medicine

- Črt Marinček, MD, PhD

Editor-in-Chief

International Journal of Rehabilitation Research

- M. Solomonow, PhD, MD(hon)

Editor-in-Chief

Journal of Electromyography \& Kinesiology

- Paolo Bonato, PhD

Editor-in-Chief

Journal of NeuroEngineering and Rehabilitation 
- Edelle [Edee] Field-Fote, PT, PhD

Editor-in-Chief

Journal of Neurologic Physical Therapy

- Guy G. Simoneau, PhD, PT

Editor-in-Chief

Journal of Orthopaedic \& Sports Physical Therapy (JOSPT)

- Mark Elkins, PhD, MHSc, BA, BPhty

Editor-in-Chief

Journal of Physiotherapy

- Stacieann C. Yuhasz, PhD

Editor-in-Chief

Journal of Rehabilitation Research and Development

• Bengt H. Sjölund, MD, DMSC

Editor-in-Chief

Journal of Rehabilitation Medicine

- Carl G. Mattacola, PhD, ATC

Editor-in-Chief

Journal of Sport Rehabilitation

- Ann Moore, PhD and Gwendolen Jull, PhD

Co-Editors-in-Chief

Manual Therapy

- Randolph J. Nudo, PhD

Editor-in-Chief

Neurorehabilitation \& Neural Repair

- Kathleen Matuska, PhD, OTR/L

Editor-in-Chief

Occupational Therapy Journal of Research: Occupation, Participation, and

Health

- Ann F Van Sant, PT, PhD

Editor-in-Chief

Pediatric Physical Therapy

- Greg Carter, MD

Consulting Editor

Physical Medicine and Rehabilitation Clinics of North America

- Rebecca L. Craik, PT, PhD

Editor-in-Chief

Physical Therapy

- Dina Brooks, PhD

Scientific Editor

Physiotherapy Canada

- Stuart M. Weinstein, MD

Editor-in-Chief

PM\&R

- Elaine L. Miller, PhD, RN

Editor-in-Chief

Rehabilitation Nursing

- Elliot J. Roth, MD

Editor-in-Chief

Topics in Stroke Rehabilitation

- Dilşad Sindel, MD

Editor-in-Chief

Turkish Journal of Physical Medicine and Rehabilitation

\section{Author details}

American Congress of Rehabilitation Medicine, 11654 Plaza America Drive, Suite 535, Reston, VA 20190, USA. ${ }^{2}$ Feinberg School of Medicine, Northwestern University, Chicago, and Center for Rehabilitation Outcomes Research, Rehabilitation Institute of Chicago, Chicago, IL 60611-2654, USA. ${ }^{3}$ Origin Editorial, LLC, Plymouth, MA 02360, USA.

Received: 20 May 2015 Accepted: 21 May 2015

Published online: 01 August 2015

\section{References}

1. Moher D, Simera I, Schulz KF, Hoey J, Altman DG. Helping editors, peer reviewers and authors improve the clarity, completeness and transparency of reporting health research. BMC Med. 2008;6:13.

2. Simera I, Altman DG, Moher D, Schulz KF, Hoey J. Guidelines for reporting health research: the EQUATOR network's survey of guideline authors. PLOS Med. 2008:5:e139.
3. Altman D. Why we need transparent reporting of health research. Excerpt from a presentation delivered at the launch of the EQUATOR Network, June 2008. Available at: http://www.equator-network.org/2008/06/26/achievingtransparency-in-reporting-health-research/. Accessed January 9, 2013.

4. EQUATOR network. Available at: www.equator-network.org/. Accessed October 21, 2013.

5. Turner L, Shamseer L, Altman DG, Schulz KF, Moher D. Does use of the CONSORT Statement impact the completeness of reporting of randomised controlled trials published in medical journals? A Cochrane review. Syst Rev. 2012;1:60.

6. Smidt N, Rutjes AWS, van der Windt DAWM, Ostelo RWJG, Bossuyt PM, Reitsma JB, et al. The quality of diagnostic accuracy studies since the STARD statement: has it improved? Neurology. 2006:67:792-797.

7. Cobo E, Cortés J, Ribera JM, Cardellach F, Selva-O'Callaghan A, Kostov B, et al. Effect of using reporting guidelines during peer review on quality of final manuscripts submitted to a biomedical journal: masked randomised trial. BMJ. 2011;343:d6783.

8. International Committee of Medical Journal Editors. Preparing a manuscript for submission to a medical journal. Available at: http://www.icmje.org/ recommendations/browse/manuscript-preparation/preparing-forsubmission.html. Accessed May 11, 2015.

9. U.S. National Library of Medicine. Research reporting guidelines and initiatives: by organization. Available at: http://www.nlm.nih.gov/services/ research_report_guide.html. Accessed October 21, 2013.

\section{Submit your next manuscript to BioMed Central and take full advantage of:}

- Convenient online submission

- Thorough peer review

- No space constraints or color figure charges

- Immediate publication on acceptance

- Inclusion in PubMed, CAS, Scopus and Google Scholar

- Research which is freely available for redistribution

Submit your manuscript at www.biomedcentral.com/submit 